\title{
SETTING UP INTEGRAL TOURIST PRODUCTS, OFFERING GREEN, ACTIVE AND HEALTHY 5* EXPERIENCES IN LANDSCAPE: MUNICIPALITY OF IVANČNA GORICA IN SLOVENIJA
}

\author{
Lea-Marija Colarič-Jakše ${ }^{1}$; Urša Kutnar ${ }^{2}$
}

\begin{abstract}
Ivančna Gorica in Slovenija is rich with cultural heritage and natural resources. In 2018, it introduced apitourism, as the Carniolan bee was first found in Ivancha Gorica. One of the problems is that the tourist offer is dispersed and not connected enough. Another problem lies in the tourist providers who fail to cooperate and work together. Since there were no integral tourist products to be found, we surveyed 213 participants. Based on the survey we assembled products, pointed out the most attractive one and gave some guidelines for further development. In the article we present the suggestions for the integral tourist products more in detail, we show the results and how article can be a basis for further research. This approach and the analysis of setting up integral tourist products can contribute to new achievements and originality. Products can enter the market after undergoing a professional examination and an upgrade.
\end{abstract}

Key Words: tourism, tourist, integral tourist product, tourist offer, apitourism

JEL classification: $Q 1, Q 2, R O, Z 3$

\section{Introduction}

"Tourism is a fast-growing industry, where people meet up, communicate, exchange information and experience new things. It represents a fundamental part of the cultural aspect of life and travel for rest, vacation and education. Tourism represents an economic opportunity for the

\footnotetext{
${ }^{1}$ Lea-Marija Colarič-Jakše, PhD, Assistant Professor, Dean at Landscape governance college GRM Novo mesto and Head of Research and development Institute Grm Novo mesto - center of biotechnic and tourism, Sevno 13, 8000 Novo mesto, +386 41322900 , e-mail: lea.colaric-jakse@vsgrm.unm.si

${ }^{2}$ Urša Kutnar, Student at Landscape governance college GRM Novo mesto, Sevno 13, 8000 Novo mesto, +386 41576 712, e-mail: kutnarursa@yahoo.com
} 
development of local and regional communities and destinations for the locals as well as for tourists visiting these destinations. A tourist product is an integral part of the tourist offer. In tourism, the product consists of a physical product as well as service and natural and cultural goods" (Turnšek Mikačić, 2019, p. 3). Depending on the number of offered tourist products, some destinations offer only one specific tourist product while others offer several integral tourist products. The Strategy for Sustainable Growth of Slovenian Tourism 2017-2021 defines a strategic vision of Slovenian tourism, with focus on several strong and market-oriented key elements and emphasizes that Slovenia is a global green boutique destination, perfect for a demanding visitor who seeks diverse and active experiences, calmness and personal growth (Ministry of Economic Development and Technology, 2017b). The municipality of Ivančna Gorica in Slovenia also has an excellent opportunity for the development of this fast-growing and strategic industry, which will only be able to maintain its competitiveness by offering unique and boutique-integral tourist products and by interconnecting and co-creating of tourist providers. Ivančna Gorica has the potential for the development of tourism and has no established integral tourist products. The area is expecting a substantial development of apiturism, as Ivančna Gorica is the birthplace of the Carniolan bee. The municipality honored the Slovenian bee with a monument of the Carniolan bee in Višnja Gora, in the immediate vicinity of a traditional apiary and a garden with honey plants. Since integral tourist products are essential for the development of tourism, we decided to research this area and design integral tourist products. Ivančna Gorica can offer various types of tourism and has many transit guests due to its ideal location. To keep the tourists in the in it for a more extended period of time and offer them the opportunity to visit several tourist attractions, we have found that it is necessary for the tourist providers, associations and other entities involved in this industry to cooperate and interconnect as well as to establish integral tourist products. In this way, the tourists could stay in the municipality the whole day and visit more sights and fully experience the tourist offer. This article sheds light on new topics and provides answers to the questions regarding which sights are most in-demand by tourists and the possibilities for further development of tourism in the area.

\section{Theoretical background - tourism and tourist}

Tourism is an economic activity that can connect small businesses in rural areas through individual and integral products. According to Brezovec, (2015) "tourism acts as a shop window for their crops, products and 
services. Through tourism, quality products and services from various activities are presented and marketed (catering, agriculture, food processing, trade crafts, cultural and artistic, sports and recreational offer, etc.). Examples of good practice show, that properly connected and marketed rural tourism products contribute to the success of small businesses, to international recognition and ultimately, to the improvement of life, demography and cohesion of rural areas" (p. 6). "Tourism includes the activities for all visitors; those who travel for one day and those who spend the night at the destination. Both groups are important for this business and the tourist product from the consumer perspective. This definition sets out two essential conditions that must be met when talking about tourism. These two essential conditions are integration and going beyond the usual living environment. The everyday living environment is an area in which people are constantly moving in connection with their routine tasks" (Mihalič, 2008, p. 8). "Tourism is a specific socio-economic phenomenon, as well as a personal understanding of spiritual and material life. In the future, the intricacy and complexity of this phenomenon, as well as its importance for the development of civilization will increase" (Besermenji, 2008, p. 5). The Statistical Office of the Republic of Slovenia (Methodological explanation; arrivals and overnight accommodation, 2019 , p. 3) states the following definition of tourism: "Tourism is an activity that contributes $t$ the economic and social development of an individual place and country as a whole". The Statistical Office of the Republic of Slovenia defines the term tourist as: "A tourist is a person who spends at least one night, but less than one year, in a place outside his usual environment, in a catering or other accommodation facility for leisure, relaxation, business or other reasons; if they are not carrying out an activity for which they receive payment in the place visited. Upon arrival, the tourist is registered in every accommodation facility in which they stay; therefore they can be registered several times during their stay in a certain place/country".

\section{A tourist product and an integral tourist product}

"A tourist product is the main part of the tourist offer. The word "product" is primarily used to describe materialized products, with a specific shape and other visible properties. In the tourist market, however, the term "product" is used primarily for services" (Cvikl \& Brezovec, 2006, p. 62). A tourist product is a combination of products and services. Therefore, we conclude that the tourist product most often tends to service, which is in many cases, combined or supplemented by products. However, we are 
aware that in tourism, the product consists of physical products as well as services and natural and cultural goods. Tourist demand is becoming increasingly complex in terms of product quality and quantity of available partial products and the possibility of choosing or combining them. Tourist companies that are not focused on a single activity (for example, catering, transport), but on the provision of various tourist services, have greater opportunities to create an integral product. "A tourist service is everything we offer tourists to satisfy their needs and desires in terms of transport, accommodation, entertainment, food and beverage, recreation, animation (Brezovec \& Nemec Rudež, 2009, p. 133)". A tourist can purchase all these services from one provider as a package of services, so-called tourist arrangement (flat holiday) or individually with different providers. A tourist product can be designed by a travel agency and offered as a tourist package or designed by direct providers of tourist services and offered on the market through promotion, such as holidays in a spa, holidays in the countryside, etc. Tourists themselves can also design a tourist product. The forms and contents of tourist services are limited only by the ability of the company or provider to identify the needs and desires of tourists and through the creativity of planners and providers of tourist services. The tourist product consists of products and services of several providers, which means that in terms of sales and perception of its scope, it has several forms, namely: partial product, flat-rate product and the total product. Depending on the number of offered tourist products, some destinations offer only one specific tourist product; others offer several possible integral tourist products. "An integral tourist product is a product that, in practice, means a set of several products and services that meet the needs of tourists when visiting a tourist destination. A new integral tourist product is a product that the municipality or destination does not yet have in its offer and with which it can raise the quality of its offer and contribute to a greater diversity of the tourist destination offer" (Ministry of Economic Development and Technology, 2017a, p. 3).

\section{Tourist market, supply and demand}

The term "tourist market" denotes a set of processes (relationships) of demand and supply. Intermediaries such as travel agencies should be excluded from the tourist exchange process. The consequence of communication between supply and demand in modern times is a reduced space for direct physical communication. We have already moved into a virtual exchange market, which is present everywhere, not just in tourism. Regardless, the tourist market has some peculiarities. Tourist 
intermediaries often link tourist supply and demand, so we can say that they are integral elements of the tourist market: "tourist supply, tourist demand and tourist intermediaries" (Čavlek et al., 2011, pp. 52-54). "From an economic point of view, demand consists of all the market forces that deal with how a customer acts and influence the customer's willingness to buy a certain quantity of goods at various prices" (Glas, 1992, p. 14). "For statistical purposes, tourist demand is defined as the number of persons involved in tourist travel or wishing to be involved in order to benefit from tourist products in places other than their place of residence" (Cooper et al., 1998, p. 24). "Tourist demand can be affected by several factors, not just price. Demand does not encompass only people who are actually involved in tourist travel, but also those who want to travel but cannot travel for various reasons. Tourist demand determines relations in the tourist market" (Colarič-Jakše \& Veljković, 2014, p. 166). "The term tourist offer refers to all market forces that influence the market behaviour of sellers or providers. An individual provider has their own supply curve, which shows their willingness to offer a certain quantity at a certain price level, all other things being equal. The set of individual offers within the market of a particular good gives a total (aggregate) offer of these goods" (Glas, 1992, p. 81). Colarič-Jakše and Veljković (2014) "represent the essential characteristics of the tourist offer, namely: Immobility or static condition (tourist demand is continuously moving); The level of the seasonality of the tourist offer (this is the only characteristics where the tourist offer and demand are similar, both are namely seasonal); Heterogeneity or diversification of the tourist offer (this occurs because there are a large number of providers on the market who create and offer tourist products); Inelasticity of the tourist supply (in contrast to the demand, the tourist supply is inelastic, which means that the supply cannot quickly change its capacity with respect to the intensity of demand)" (pp. 174-175).

\section{Tourist offer in the countryside}

Through sustainable and expertly marketed tourism, the countryside can exhibit and sell its crops and products while maintaining its vitality and its values. The model of sustainable marketing is based on the assumption of responsible and ethical tourism, which has the function of preserving natural, cultural and human resources in rural areas. Sustainable marketing provides long-term benefits for entrepreneurs, agricultural activity and the local community. It provides the following benefits to the countryside as a tourist destination (Brezovec, 2015): "greater economic diversification of rural areas; longer stay and higher consumption of guests; higher demand 
for local products; higher incomes for farmers; infrastructure maintenance; new jobs opportunities in tourism and tourism-related activities; greater economic stability" (p. 9). The strategic guidelines for the marketing of rural tourism are directed not only towards attracting tourists (external marketing) but also towards internal stakeholders - entrepreneurs, creators, residents of the area (so-called internal marketing). The importance of internal marketing of rural tourism is that the internal stakeholders systematically develop networking to achieve positive effects of tourism on the area.

\section{Method and results}

We used the method of the theoretical approach to our research as we first studied the professional literature on the topic, reviewed the promotional materials of the municipality of Ivančna Gorica and analyzed the content on their website www.ivancna-gorica.si. In the empirical part, we prepared and conducted a survey and research, which established the current state of tourism in the municipality of Ivančna Gorica and obtained starting points for the establishment of integral tourist products. We surveyed citizens and people who have visited the municipality at least once. The survey was conducted from 3 February 2019 to 31 May 2019, where we gathered answers from 213 respondents. We made a SWOT analysis, based on which we identified the strengths, weaknesses, opportunities, and threats to the development of tourism and integral tourist products. Based on the research, we interpreted the obtained data and designed integral tourist products. Before starting the research (Kutnar, 2019), we set three hypotheses: H1: The municipality of Ivančna Gorica has well-developed tourist products; H2: The municipality of Ivančna Gorica has no integral tourist products; H3: The slogan "Comfortable and Homelike" contributes to better recognition.

\section{Influence on the development and organization of tourism}

Respondents were asked who in their opinion, most influences the development and organization of tourism in Ivančna Gorica. The lowest number of respondents indicated "Other", seven respondents stated that they did not know who influences the development and organization of tourism most, and eight respondents stated local associations and citizens have the most influence. The majority of the respondents believe that individual tourism providers ( 58 respondents) and tourist associations have the most influence. 
Figure 1: Influence on the development and organization of tourism

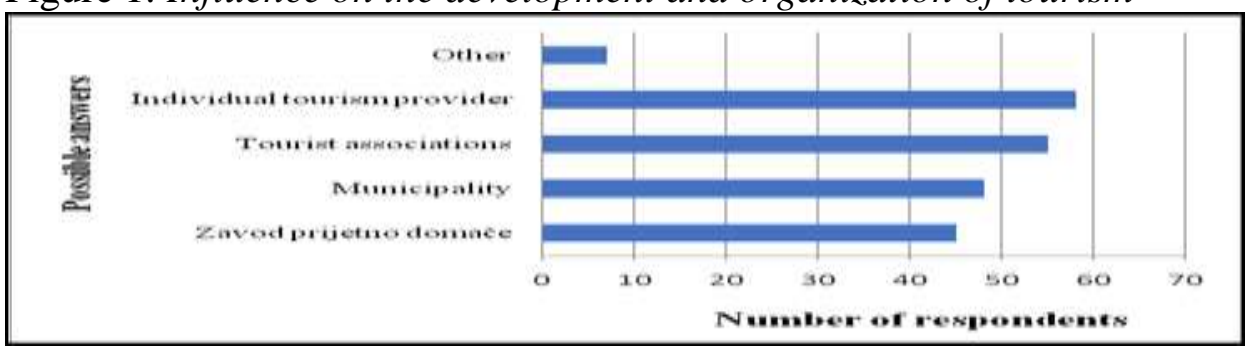

Source: Prepared by the authors

\section{Recognition of the slogan "Comfortable and homelike", under which the municipality presents itself as a tourist destination}

Respondents were asked about the recognisability of the municipality's slogan. As many as $62 \%$ of those asked know the "Comfortable and homelike" slogan, and $38 \%$ of those asked do not know it. Municipality of Ivančna Gorica is one of the rare municipalities that has a slogan which is becoming more and more recognizable (Figure 2).

Figure 2: Recognition of the slogan "Comfortable and homelike", under which the municipality presents itself as a tourist destination

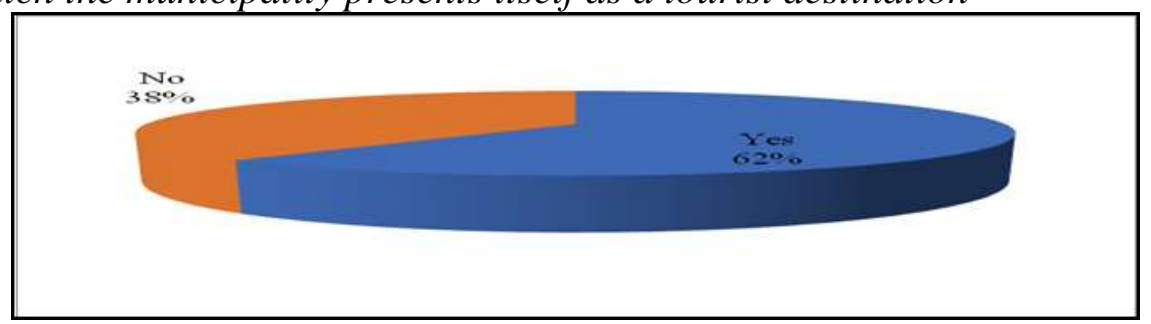

Source: Prepared by the authors

\section{The importance of the slogan for presenting the municipality as a tourist destination}

We asked the respondents how much the slogan helps when presenting and promoting it as a tourist destination. The majority of respondents (109) consider the slogan to be very important. According to 49 respondents, the only people who know the slogan are the ones living in it and the ones who have already visited it. Of those people asked, 55 stated that the promotion of the municipality was fine without the slogan (Figure 3 ). 
Figure 3: The importance of the slogan for presenting the municipality

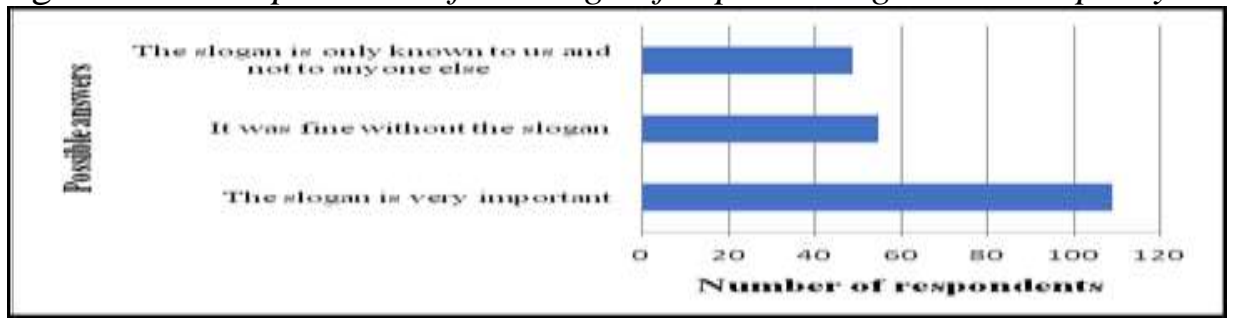

Source: Prepared by the authors

\section{Most known tourist attractions in the municipality of Ivančna Gorica}

We asked the respondents to rate the recognisability of tourist attractions in the municipality of Ivančna Gorica. Respondents had to rate the recognisability of a tourist attraction from 1 (lowest recognisability) to 7 (highest recognisability). The results are presented in Figure 5, according to the average rating for individual attraction. Based on the answers, we can observe that the highest average rating was assigned to natural tourism. Beekeeping tourism and "other" received the lowest recognisability rating. For "Other", respondents named Nina Pušlar, Reka ljubezni ("River of Love"), All-Slovenia fair, Excursion Tourism and Farms, outdoor play in Muljava, and "I do not know".

Figure 4: Most known tourist attractions in Ivančna Gorica

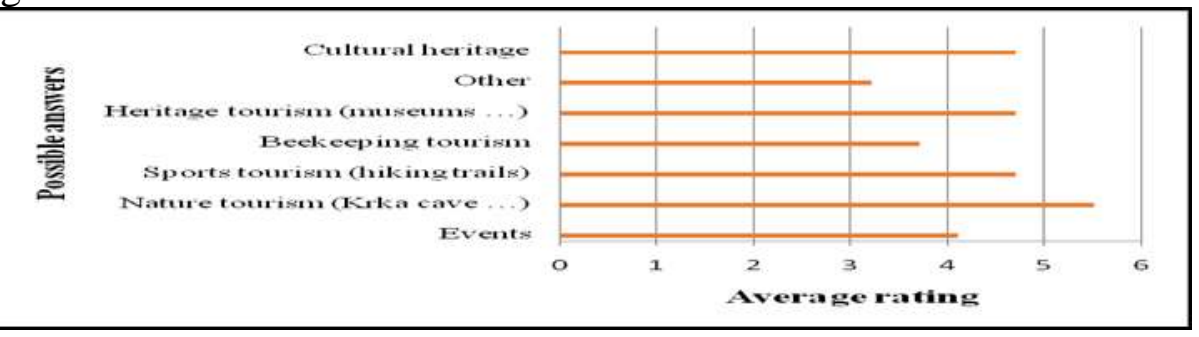

Source: Prepared by the authors

\section{Recognisability of Ivančna Gorica by types of events}

We asked the respondents to rate the recognisability of events in the municipality of Ivančna Gorica. Respondents had to rate the recognisability of a tourist attraction from 1 (lowest recognizability) to 5 (highest recognisability). The average ratings are presented in Figure 5. The highest average rating was assigned to the hike along the Jurčič Trail (4.4) The lowest average score was assigned to workshops (2.4). 
Figure 5: Recognisability of the municipality by types of events

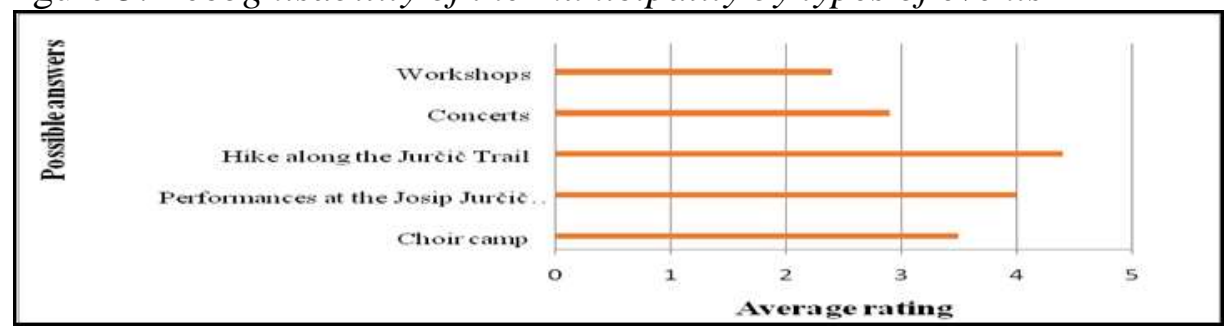

Source: Prepared by the authors

\section{Interest in integral tourist product}

We asked the respondents if they would be interested in an integral tourism product that would also include a hike or a different activity. The majority, 73 respondents, stated that they would be quite interested, 59 respondents stated they would be slightly interested and only 20 respondents would not be interested in the proposed integral tourism product (Figure 6).

Figure 6: Interest in integral tourism product

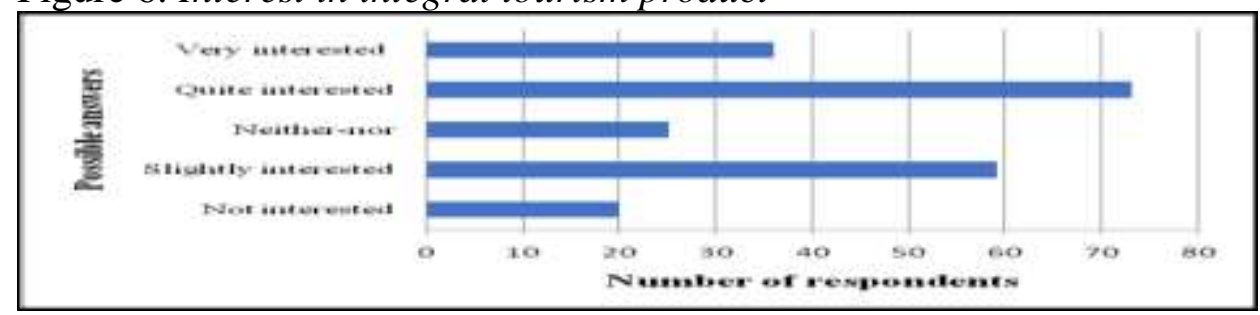

Source: Prepared by the authors

\section{Assessment of the proposed integral products}

We asked the respondents to rate the proposed integral products in municipality. Respondents had to rate the products from 1 (lowest rating) to 5 (highest rating). The average ratings of proposed integral products are presented in Figure 7. The highest average rating was assigned to the product Active on the green pearl ("Aktivni na zelenem biseru") and Land of the tenth brother ("Dežela Desetega brata") got the lowest rating. 
Figure 7: Assessment of the proposed integral products

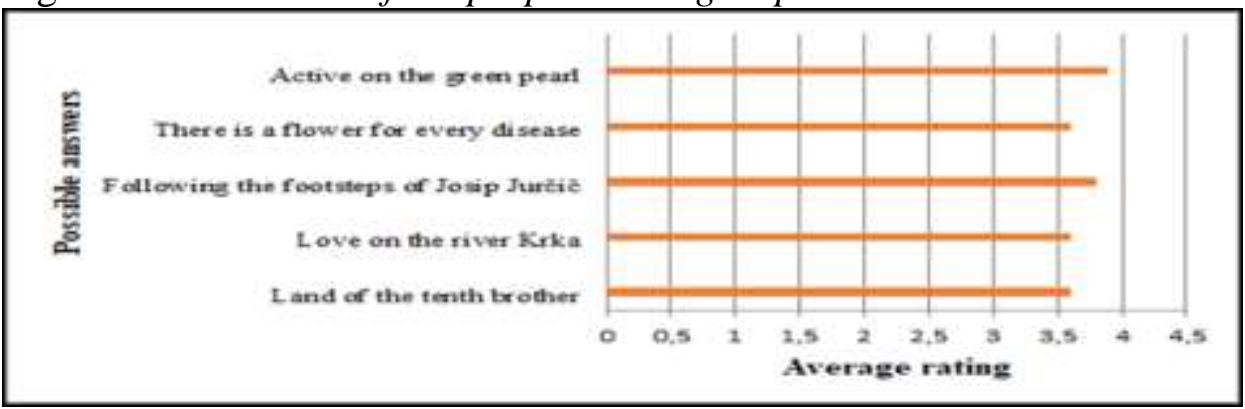

Source: Prepared by the authors

\section{Assessment of tourism development in Ivančna Gorica}

We asked the respondents to assess the development of tourism in the the municipality of Ivančna Gorica. The majority of those asked reported that tourism is developing slowly, and only 34 respondents believe that tourism in the municipality is poorly developed (Figure 8).

Figure 8: Assessment of tourism development in the Ivančna Gorica

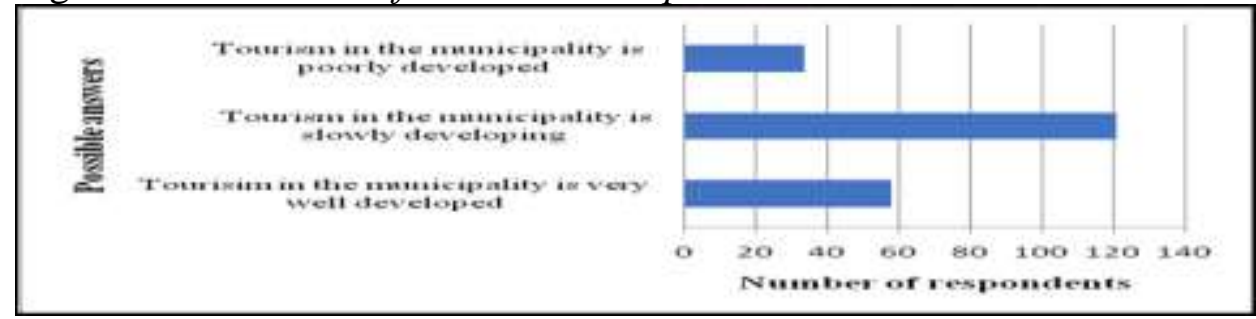

Source: Prepared by the authors

\section{Discussion}

\section{The concept for the establishment of integral tourist products}

Lisi and Esposito (2015) state that "integral tourism can be defined as a type of tourism that is specifically related to the environment in which it is carried out and has, in practical terms, a clear connection with local resources, activities, products, the production and service industry, and also works with the local community. The goal of integral tourism is twofold. Due to different interests, requirements and needs, the goal of such tourism is to merge into a common, integral strategic tourism plan. The goal of tourism is planning with the aim of being united in the social and economic life of the region and its community. Although it has been proven that some 
tourist destinations have developed without a conscious strategy and integration, many destinations have suffered unwanted consequences (physical, human, marketing, organizational impacts). These led to their downfall. Integral tourism has proven to be crucial in the sustainable development of rural areas (so-called integral rural tourism)" (pp. 246247). Given the potential of supply and demand for rural tourism in the area, we recommend the development of some umbrella products in the area, which can be developed into integral tourist products. When designing the offer, the core of it should be the so-called umbrella concept of the Ivančna Gorica product, which combines the most important needs and expectations of target market groups and the benefits that the rural area can offer. The meaning of the umbrella concept is to promote the visibility, diversity and competitiveness of the tourist offer in selected market segments. For the umbrella concept of tourist products of the considered rural area, Brezovec (2015) proposes the concept 5E - "Eco, Ethno, Ethics, Esthetics, Energy: Eco: as an emphasis on nature conservation (in accommodation, food, products, creative workshops, sports and recreational activities); Ethno: as the inclusion of elements of the area's heritage in the basic (food and accommodation) and supplementary tourist offer of the area (e.g. stories of past heritage, inclusion in the still-active heritage, e.g. on tourist farms); Ethics: as responsible tourism - considerate, respectful "consumption" and interpretation of the nature and culture of the area; emphasizing coexistence and respect; Esthetics: as an added value to tourist observation (e.g. including sightseeing); and experiencing accommodation and food services (tidiness, thoughtful design); it can also be used as an independent component of products with an emphasis on beauty (care, spa) or art (photography, art, film tourism); Energy: as a promotion of vitality (sports, recreation, health, wellness, healing, spirituality, personal growth, co-creation, learning)" (p. 31).

We design a tourist product on the basis of six contents: where we are at the moment, what we want to achieve by designing a tourist product, how we will design it and test its development which includes 4p's (product, price, place, promotion), start-up and monitoring. Within the core of demand of all segments of tourists, which we have identified as potential and sustainable tourists in the rural area of Ivančna Gorica, are nature activities and gastronomy. We address those tourists who appreciate and seek pure nature and healthy (typical, local, seasonal, home-grown, quality) food. Their active attitude and respect for the countryside also give rise to other interests, wishes and needs, which providers know how to offer in an appropriate way at the right time in the right place. Defining a product 
category is a type of rural tourism with a touch of innovation and creativity. The brands developed by the providers should reflect this view, which is a key advantage for the selected target segments - tourists will get a guaranteed high standard and consistent authenticity, but in an interesting way, with a new story that will be of special value to them. The source of trust in the rural tourist product lies in the inseparable connection of providers with the countryside, nature and culture throughout the year. The target segments are an important area since each integral tourist product has its own target group. Thus the products called "Aktivni na zelenem biseru" ("Active on the green pearl") and "Dežela Desetega brata" ("Land of the Tenth Brother") are suitable for active, young people, especially for primary and secondary school students and higher education students. The integral product "Po sledeh Josipa Jurčiča" ("Following the footsteps of Josip Jurčič") is intended for everyone, as it includes activities that are suitable for both young and old. "Za vsako bolezen rož'ca raste" ("There is a flower for every disease") is especially suitable for the elderly who appreciate homemade remedies and for young people who are becoming increasingly interested in natural ways of healing diseases. It could also be suitable for people who like to learn about homemade herbal remedies. "Ljubezen na reki Krki" ("Love on the river Krka") is intended for fans of the TV series Reka ljubezni, who would like to visit the destination they see on the TV. Creators of tourist products must be increasingly creative and innovative in the design of products, as they are forced to do so by strong competition and the increasingly developed needs and requirements of representatives of modern society. We can get a new product by developing it in our company by buying a franchise or through cooperation. Many new tourist products are not commercially successful. This can be avoided by carefully and meticulously developing new products, where increasing emphasis is placed on sustainable development. Since we have found in the research of the tourist offer of the of Ivančna Gorica that no integral tourist products yet exist, we have designed integral tourist products on the basis of the study, which we present below (Kutnar, 2019).

Dežela desetega brata ("Land of the Tenth Brother"): Within the integral tourist product, named after the first Slovenian novel, we planned a hike along the selected part of the "Comfortable and homelike" route. Tourists can choose the part they wish to walk based on their psychophysical abilities. This product is based on the premise that some tourists have fond childhood memories that took place in Ivančna Gorica, and they can explore those areas without the use of a car. During their trip, they could visit a museum or have lunch on a tourist farm located in the 
vicinity. This product could be not only available as a one day trip but also a more extended vacation. The vacation would focus on sports tourism where tourists could set off on the "Comfortable and homelike" route from one of the local communities and walk the entire circular route in three to four days. The tourists would spend the night on a tourist farm where they would have the opportunity to enjoy the local cuisine.

Ljubezen na reki Krki ("Love on the river Krka"): The trail Ljubezen na reki Krki ("Love on the river Krka") is designed in such way, that visitors can see the filming locations of the popular TV series Reka ljubezni ("The river of love"). The tourist product Ljubezen na reki Krki is designed in the same way. So, tourists first watch a video of how the TV series was filmed and the funny clips and interviews with the actors about which landmark is their favorite. Then they walk the trail of Reka ljubezni, which shows the filming locations they saw on the TV. Along the way, they visit a well-known pilgrimage church of Saints Cosmas and Damian, the spring of the river Krka and the spring of the Poltarica river. Then, the visitors drive to Muljava, where they visit the Josip Jurčič Museum, have lunch at the inn and swim in the Krka river.

Po sledeh Josipa Jurčiča: The trail Ljubezen na reki Krki ("Love on the river Krka") is designed in such way, that visitors can see the filming locations of the popular TV series Reka ljubezni ("The river of love"). The tourist product Ljubezen na reki Krki is designed in the same way. So, tourists first watch a video of how the TV series was filmed and the funny clips and interviews with the actors about which landmark is their favorite. Then they walk the trail of Reka ljubezni, which shows the filming locations they saw on the TV. Along the way, they visit a well-known pilgrimage church of Saints Cosmas and Damian, the spring of the river Krka and the spring of the Poltarica river. Then, the visitors drive to Muljava, where they visit the Josip Jurčič Museum, have lunch, and when the temperatures are suitable, visitors can also swim in the Krka river.

\section{Za vsako bolezen rož'ca raste ("There is a flower for every disease"):}

In Stična, people have long been associated with nature and herbs. The late Father Simon Ašič the person responsible for that. This integral tourist product came to be due to the great historical and cultural significance of both Stična and Father Ašič. Tourists would first visit the Christian Museum in Stična, and after the tour they would go to the SITIK store, where they would have the opportunity to buy teas and herbal preparations. Additionally, we could hold a tea ceremony in the tea room and educational 
seminars on medicinal herbs. The seminars would educate people on when and which herbs to pick and many other important topics. The trip would be concluded with lunch at the farm.

Aktivni na zelenem biseru ("Active on the green pearl"): The Krka river offers many opportunities for actively spending your free time and unforgettable experiences, such as fishing or swimming in the river. We focused on other activities in our tourist product. We have planned to start the day with a tour of the Krka Cave, then take a kayak ride on the Krka river, have lunch and return to the starting point.

Od rože do medu - apiturizem ("From flower to honey - apitourism"): With the unveiling of the House of the Carniolan Bee, it will be possible to develop a unique integral tourist product dedicated to Carniolan lavender, namely "From flower to honey". With this integral product, visitors would get the opportunity to learn about the path from flowers to honey and other bee products. Visitors would first see a park of honey plants and learn about their properties and importance. The park tour would be followed by a tour of the apiary, observing the behaviour of bees and getting to know the body parts of the bee. During the tour of the apiary, visitors would be able to see how it is built and its other non visual attributes. This would be followed by a tour of the house of Carniolan bee and a presentation of a film about Carniolan bee. A tasting of bee products would conclude the visit. We would create an additional programme for children that would be similar to the programme described above only that it would be adapted to the children. There would be a great emphasis on education about the importance of bees for human existence and food production as well as on how honey can be used for culinary and health purposes. There are numerous opportunities due to apitherapy and the culinary world especially in the period when the International Institute of Gastronomy, Culture, Arts and Tourism named Slovenia the holder of the title "European Gastronomic Region 2021". Apitourism in Slovenia transforms the rich Slovenian apiculture into a unique travel experience, which is also the primary integral tourist product of our research. Apitourism contributes to a higher quality of life, educates people and develops a high level of respect and responsibility for the natural, cultural and social environment as well as emphasizes the values of health, family, creativity, connection, harmony and the importance of fulfilment in life. It brings Slovenia closer to the ideal of a healthy destination, known as a country of hospitable people, and above all as a homeland of excellent beekeepers with rich apiculture and centuries-old beekeeping practices developed by beekeepers. The 
philosophy of this relatively new branch of tourism is based on the observance of natural laws - the functioning and importance of bees can be reflected in the functioning and importance of man and his realization of values such as belonging, organization, diligence, respect, harmony. Adding the trend of travelling to green, eco, health-oriented and satisfaction-oriented destinations and the rise of creative tourism, we can speak of integrated sustainable tourism.

\section{Vision, mission and strategic goals of rural tourism in Ivančna Gorica}

Based on the analysis of the state and opportunities of rural tourism and the definition of its identity, we set the direction of the development of tourist products. We define this by vision, mission and strategic goals. Vision defines what the rural area wants to become or in which direction it wants to develop its integral tourist products - the source for the vision are the advantages of the destination. The vision of rural tourism for Ivančna Gorica is: The area will become attractive for creative people to live and work and for spending their leisure time. It will become a recognizable tourist destination with natural and cultural sights and a connected, quality and authentic tourist offer. It will be renowned for its excellent typical cuisine and top-quality products related to nature. The design of integral tourist products in rural areas must follow the vision and contribute to its realization. Tourist products must be integral into combinations (packages) of services, products and experiences that will make sense and satisfy the specific needs of selected tourist segments or into integral tourist products. The importance of designing and marketing common rural tourist products is, therefore in rising demand. Tourists/buyers will more easily find, recognize, evaluate and buy the integral tourist product and with that also the rural area. They will recognize and pay for the added value of transport, services, products and experiences that will be combined, making a coherent unit. The mission of integral tourist products in realizing the vision of rural tourism is: "bringing together tourism and tourism-related providers in rural areas; raising the demand for their products and services; competitively satisfying the needs of selected segments of tourists (without negative impacts on the natural and social environment) and increasing the visibility, quality and recognition of brands of the countryside" (Brezovec, 2015, p.18). Based on the research, we have confirmed all three hypotheses. The first hypothesis "The municipality of Ivančna Gorica has welldeveloped tourist products" has been confirmed. While studying the tourist products, we have found that they are well developed, and the overall image of it is at a high level. The second hypothesis "The municipality of Ivančna 
Gorica has no integral tourist products" has been confirmed. Even though it is rich in various tourist products, it currently has no integral products. The third hypothesis "The slogan Comfortable and Homelike" contributes to better recognition of the municipality" was confirmed on the basis of a survey completed by citizens and visitors to the municipality. According to Colarič-Jakše (2017), "tourism is an industry that enriches wider local life and brings added value to the social environment. In order to strengthen the desired tourist image and identity of the common tourist product, the marketing of brands should systematically develop and realize the following promises: a functional set of promises (e.g. offer of authentic rural products, offer of quality and authentic tourist services, quality tourist infrastructure, aesthetics); the emotional set of promises (the benevolence and beauty of nature, the power and healing of climate and air, the pleasures and intoxication of tastes, the invigorating effects on human health and well-being and interpersonal relationships); an experiential set of promises (tours and experiences based on the natural and cultural sights of the rural area, service and experience of typical cuisine, experience of a typical ambience, the experience of genuine contact with the locals)" (p. 2).

\section{Conclusion}

Colarič-Jakše (2017) "finds that tourism is an important industry that enriches wider local life and brings added value to the social environment. It is a mirror of the identity of society, culture and wider area, which connects the world and the micro-economy into a wholesome image of a specific area. Tourism is one of the fastest-growing industries and strategic aspects of development, which achieves growth with the growth of new tourist areas. In the flood of supply, it builds its competitive advantage on the image of the environment, high quality and tourist satisfaction, and as a product, it is a synergy of professionalism, authenticity, diversity, attractiveness and hospitality. Tourism is a generator of development in a specific area, where the competitiveness of the global offer creates a high level of knowledge, professionalism, innovation, creativity, quality and excellence" (p. 2). The tourist activity in Slovenia is expanding very fast we can already encounter the beginnings of integral tourist products or sometimes even end products in almost every local or regional community. However, we must not forget about the integration and cooperation of tourism providers and the integration of the offer and its quality. Tourism activity is also on the rise in Slovenia, as new and attractive tourist products and integral tourist products, including 5-star experiences, are being created. Ivančna Gorica is already a popular tourist destination due to its 
location, which is extremely transit, it lies halfway between Ljubljana and Novo mesto. Based on the research, we came to the realization that it has many anthropogenic and natural attractions and that it is a land of many gems that its citizens can be proud of. In the past, the municipality built its recognition on the fact that the writer of the first Slovenian novel, Josip Jurčič, was born in Muljava but in the last five years, the Slovenian TV series Reka ljubezni ("The river of love") has made it attractive to visitors. The shots that the creators of the series showed to the viewers on television screens contributed to attracting visitors in large numbers, to see this tourist spot and the surrounding sights. We believe that Ivančna Gorica has great potential to become a tourist-recognizable destination with attractive integral tourist products, where apiturism stands out.

\section{References}

1. Besermenji, S. (2008). Uvod u turizam, Univerzitet u Novom Sadu, Prirodno-matematički fakultet, Departman za geografiju, turizam i hotelijerstvo, Novi Sad.

2. Brezovec, A. (2015). Smernice za oblikovanje in trženje skupnih turističnih produktov na podeželju, Univerza na primorskem, fakulteta za turistične študije - Turistica, Portorož, Sveučilište u Rijeci, Fakultet za menadžment u turizmu i ugostiteljstvu, Opatija.

3. Brezovec, A., Nemec - Rudež, H. (2009). Marketing v turizmu: izhodišča za ustvarjalno razmišljanje in upravljanje, Fakulteta za turistične študije Turistica, Portorož.

4. Colarič-Jakše, L.M. (2017). Sodelovalno mreženje in izraba inovacijskega potenciala $v$ turističnem prostoru, Fakulteta za organizacijske študije v Novem mestu, Novo mesto.

5. Colarič-Jakše, L., Veljković, B. (2014). Turizem. Uvod v osnove in teorijo turizma, Fakulteta za turizem, Maribor.

6. Cooper, C., Fletcher, J., Gilbert, D., Wanhill, S. (1998). Tourism Principles and Practice, Addison Wesley Longman Publishing, New York.

7. Cvikl, H., Brezovec, T. (2006). Uvod v turizem, Turistica - visoka šola za turizem, Portorož. 
8. Čavlek, N., Bartoluci, M., Prebežac, D., Kesar, O. (2011). Turizam ekonomske osnove i organizacijski sustav, Školska knjiga, Zagreb.

9. Glas, M. (1992). Ekonomija, Državna založba Slovenije, Ljubljana.

10. Kutnar, U. (2019). Vzpostavitev integralnih turističnih proizvodov v občini Ivančna Gorica, Diplomska naloga, Visoka šola za upravljanje podeželja GRM Novo mesto, Novo mesto.

11. Lisi F. A., Esposito F. (2015). An AI Application to Integrated Tourism Planning. Congress of the Italian Association for Artificial Intelligence AI*IA 2015, 9336, 246-259.

12. Mihalič, T. (2008). Turizem: ekonomski vidiki, Ekonomska fakulteta, Ljubljana.

13. Ministry of Economic Development and Technology, (2017a), Javni razpis za sofinanciranje razvoja in promocije integralnih produktov turističnega gospodarstva, https://www.uradni-list.si/glasilo-uradni-listrs/vsebina/2017004200001/javni-razpis-za-sofinanciranje-razvoja-inpromocije-integralnih-produktov-turisticnega-gospodarstva-st--430011201715-ob-279117, (1 May 2019).

14. Ministry of Economic Development and Technology, (2017b), Strategija trajnostne rasti slovenskega turizma 2017-2021, http://www.mgrt.gov.si/fileadmin/mgrt.gov.si/pageuploads/Strategija_turi zem_koncno_5.10.2017.pdf, (1 May 2019).

15. Republic of Slovenia, Statistical office, Methodological explanation; arrivals and overnight accommodation, (2019), p.3, https://www.stat.si/ StatWeb/File/DocSysFile/7779, (4 May 2019).

16. Turnšek-Mikačić, M. (2019). Trženjski splet na podeželju, Priročnik, Visoka šola za upravljanje podeželja GRM Novo mesto, Novo mesto. 